\title{
As Moléculas da cor na Arte e na Natureza
}

A cor fascinou o homem desde sempre. O fenómeno da cor pode ter várias origens; desde a dispersão à absorção de luz, um diversificado número de fenómenos origina as cores que a natureza apresenta. Para os químicos, o que dá cor são as moléculas, a que outros chamam pigmentos ou corantes. As fontes de pigmentos para produzir cor na antiguidade eram, no entanto, limitadas. Nos nossos dias, existem milhares de corantes sintéticos; ao contrário, na antiguidade, o homem tinha à sua disposição algumas poucas dezenas, cujos segredos de aplicação eram cuidadosamen- te guardados. Aqui procura-se dar uma ideia de como foram obtidos e utilizados pelos nossos antepassados, os vermelhos, azuis e amarelos orgânicos. Da célebre alizarina que foi, sem dúvida, a fonte de vermelho por excelência, até ao século passado, ao mítico índigo - o "tekhelet" dos Hebreus - o azul ainda hoje usado para tingir as calças de ganga, passando pelos amarelos (flavonóides, açafrão) e acabando no primeiro corante inteiramente sintético (a "malva"), i.e., nunca "produzido" pela natureza, de tudo aqui se tratará.

\section{O fenómeno da cor}

A cor é um tema comum e unificador a diversas ciências. $\mathrm{O}$ estudo das suas origens, da sua percepção, dos seus usos, leva-nos a encontrar astrónomos, físicos, médicos, conservadores de Arte, químicos, e muitos outros, com ela envolvidos. Qualquer tentativa de definição da cor peca, sempre, por ser parcial e redutora. Assim, e como químicos de base que somos, mas também como observadores deliciados com as cores que os antigos nos trouxeram, faremos aqui uma ligação entre o mundo químico dos pigmentos/corantes e a Arte que eles ajudaram a criar.

Por uma questão de importância e também da necessária concisão deste trabalho, as cores e origens destas encontrar-se-ão principalmente restringidas ao vermelho, azul e amarelo de corantes orgânicos utilizados desde a Antiguidade. Para uma abordagem dos modernos corantes sintéticos ver, p.e.,

\footnotetext{
1 Departamento de Química da Universidade de Coimbra, 3004-535 Coimbra

2 Departamento de Conservação e Restauro e REQUIMTE-CQFB, Universidade Nova de Lisboa, Quinta da Torre, 2825 Monte de Caparica
}

o artigo de J. Moura [1] e referências aí citadas. Para os pigmentos históricos consultem-se os trabalhos de referência do Professor Peixoto Cabral [2-4].

Antes das cores, e porque o químico cientista assim o exige, uma breve introdução à forma como a luz interage com a matéria.

\section{Os enigmas da cor}

A abordagem das teorias da cor é, obviamente, complexa. Tentar quantificar e racionalizar algo que produz emoções e brinca com os nossos sentidos de forma tão directa será sempre um desvendar de enigmas [5]. No caso dos corantes orgânicos, que iremos abordar, a cor encontra-se relacionada com transições electrónicas que ocorrem com energias da zona do visível. Qualquer um de nós se encontra familiarizado com as cores espectrais e o prisma que as difracta/separa. No entanto, existem muitos enigmas no fenómeno da cor. Por exemplo, porque que é que o amarelo e o azul originam o verde?

A cor de um corante é obviamente devida ao facto das substâncias ab- sorverem (pelo menos parcialmente) componentes da luz visível. Uma visão simplificada da teoria electrónica das cores dos corantes (moléculas com cor) permite concluir que de entre outros factores, que tornam uma cor mais intensa, se encontram o tamanho da molécula (no caso desta ser constituída por ligações simples e duplas alternadas conjugação) e a substituição de átomos de carbono, hidrogénio e oxigénio por outros electro-doadores ou aceitadores ou de efeito indutivo [6].

\section{Interacção da luz com um material transparente}

De uma forma muito simplificada, podemos considerar a luz a interactuar de diferentes formas com um material transparente (ver figura 1) [7].

A luz que incide pode ser imediatamente reflectida em qualquer face do material. A luz que passa através deste material pode ser dispersa ou absorvida. Se parte da luz absorvida é reemitida, normalmente com valores de energia inferiores, temos o fenómeno de luminescência (fluorescência ou fosfores- 


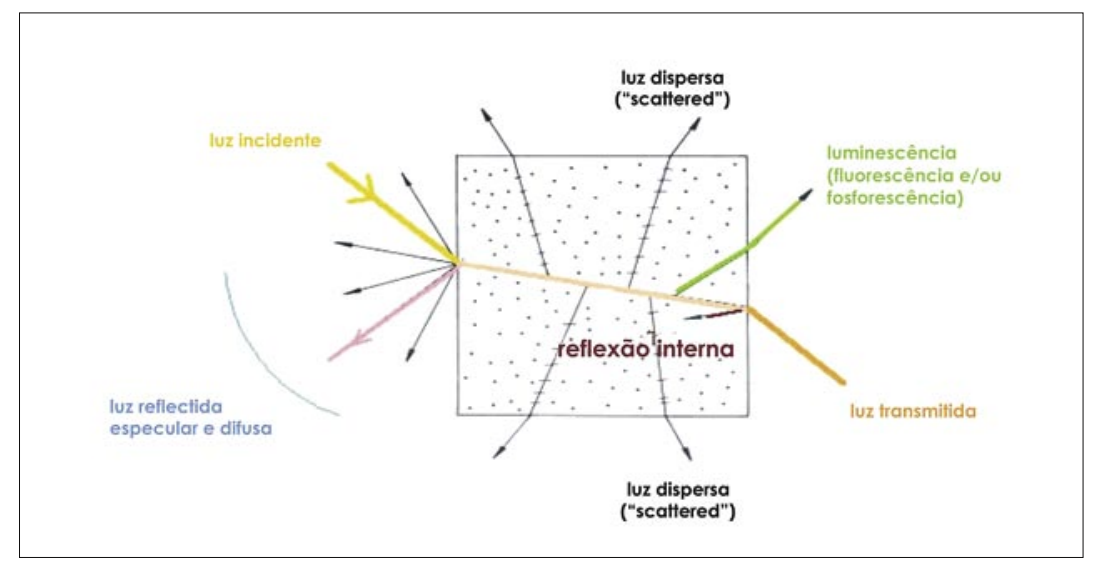

Figura 1 Interacção da luz com um material transparente. (adaptado das referências [7] e [8])

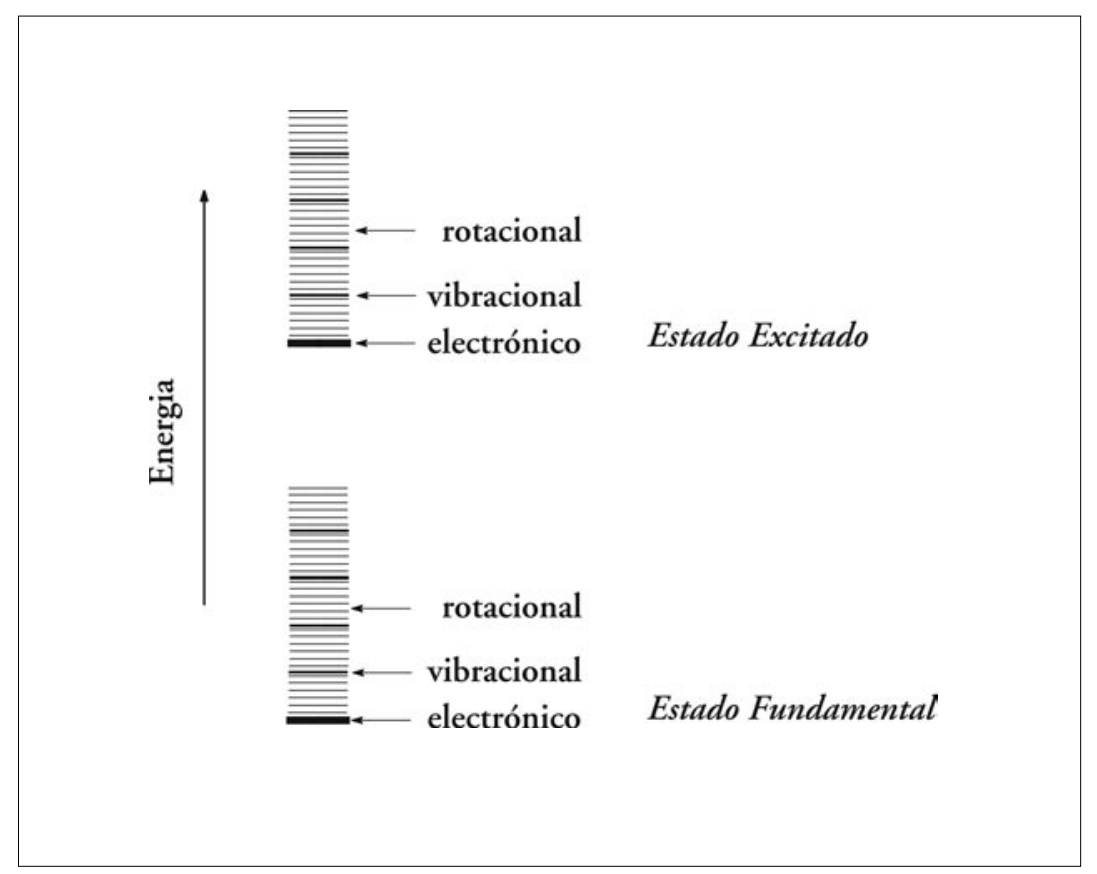

Figura 2 Representação esquemática dos niveis energéticos electrónicos, vibracionais e rotacionais de uma molécula.

\section{Comprimento de onda (nm)}

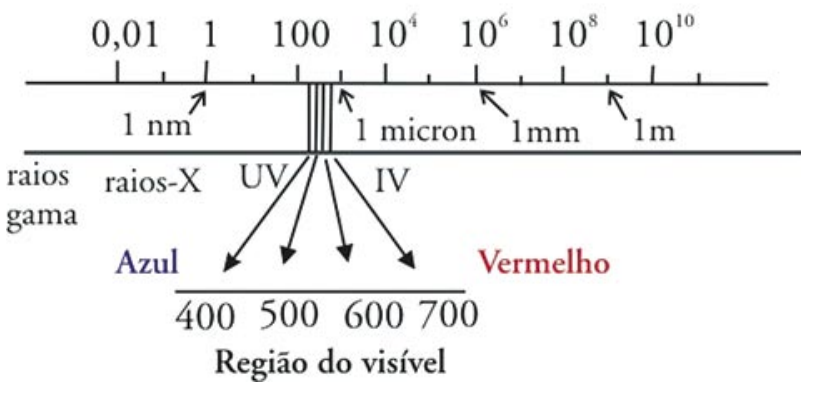

Figura 3 Espectro electromagnético cência). A luz que atravessa o material é a luz transmitida. Todos estes processos podem dar origem à produção de cor. Existe um outro fenómeno de interacção da luz com o material, não ilustrado na figura 1, que se designa por refracção. Este é característico do material, originando um desvio na transmissão de luz, com um determinado ângulo, a que corresponderá uma determinada frequência de propagação da luz e como tal uma certa cor; o seu valor dependerá do ângulo de incidência da luz e da diferença dos índices de refracção. Este fenómeno é o responsável por muitas das cores "físicas" observadas nos animais, como p.e. na magia das asas de uma borboleta, na magnificência da cauda de um pavão, etc [5,8]. Quando não existe um ângulo privilegiado para a passagem da luz, ou seja, quando o meio não é transparente e a luz é dispersa em todas as direcções, caoticamente, esta designa-se por luz dispersa.

\section{A cor a partir das moléculas}

Enquanto que num gás os átomos emitem luz a comprimentos de onda bem determinados dando origem a uma série de linhas finas, as moléculas emitem um conjunto de bandas. No entanto, dependendo da natureza da própria molécula ou de factores externos (solvente, temperatura, etc.), estas bandas podem ser resolvidas numa série de linhas (mais propriamente bandas resolvidas vibracionalmente) mais ou menos espaçadas. A origem das bandas de absorção (e de emissão) reside no facto de a cada transição electrónica se associarem novos níveis energéticos devidos às vibrações e rotações da molécula. Desta forma, uma transição entre dois estados electrónicos que num átomo corresponderia a uma simples linha, ocorre numa molécula como um conjunto de linhas: uma banda.

As transições electrónicas podem acontecer no ultra-violeta (200-400 nm), visível (400-720 nm) ou ainda no infravermelho próximo (720- $2000 \mathrm{~nm}$ ). O espaçamento entre os níveis vibracionais é cerca de $1 / 10$ do observado para os níveis electrónicos (p.e. 3,7 eV ou $335 \mathrm{~nm}$ ), dando origem a diferenças energéticas da ordem de $\Delta \mathrm{E} \approx 6 \times 10^{-20} \mathrm{~J}$ 


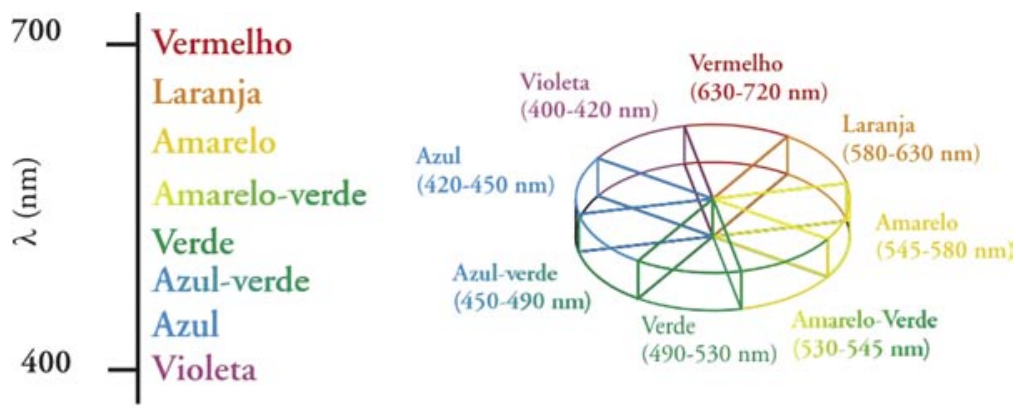

Figura 4 A Roda, juntamente com os intervalos de comprimentos de onda e cores observadas.

(0,37 eV ou 3350 nm) e absorção e emissão na região do infravermelho. Por fim, o espaçamento entre os níveis energéticos rotacionais é cerca de $1 / 100$ dos anteriores, encontrando-se com níveis energéticos rotacionais de, aproximadamente, $\Delta \mathrm{E} \approx 6 \times 10^{-22}$ J $(0,0037 \mathrm{eV}$ ou $335130 \mathrm{~nm}$ !!) originando então, absorção e emissão na região das micro-ondas. Estas escalas de comprimentos de onda encontram-se englobadas no bem conhecido espectro electromagnético (ver Figura 3).

A cor resulta pois da absorção de luz na região do visível (400-720 nm). 0 objecto absorve então parte da luz que Ihe incide, transmitindo a restante. Se for luz branca (mistura de luz de diferentes cores) que incide num objecto, a remoção, por absorção, de qualquer uma destas cores da luz branca, resulta na transmissão de todas as outras, o que por vezes se traduz na observação da cor complementar, ver Figura 4. Um exemplo é o que resulta da origem da cor apresentada pelas folhas verdes e de uma forma geral por todas as formas de vegetação, resulta da absorção da clorofila nas regiões do vermelho e do azul, não sendo a luz verde absorvida em quantidade significativa, ver Figura 5.

\section{As Cores na Natureza - o que se vê}

A paleta de cores oferecida pela Natureza é muito vasta: desde os deslumbrantes vermelhos, azuis e amarelos de flores e frutos, até às cores, bem mais estáveis, escondidas em raízes e folhas e ainda os castanhos e pretos.

Os castanhos e pretos com diferentes intensidades e tonalidades são abundantes na natureza. Estas cores advêm das melaninas que dão as cores pretas e castanhas, por exemplo ao cabelo, à pele, ao castanho dos frutos danificados, etc. A eumelanina (uma melanina portanto), principal responsável pela cor preta, é um polímero complexo constituído por difenóis e outras moléculas afins. Uma parte da estrutura que constitui uma das muitas formas da eumelanina encontra-se apresentada na Figura 6. Note-se que existe uma possibilidade de conjugação ${ }^{1}$ bastante eficiente o que conduz à cor negra deste polímero.

\section{Nas flores \& frutos}

Polifenóis

Os polifenóis constituem um grupo muito diversificado de compostos que dão origem às cores brancas, amarelas, vermelhas e azuis de muitas plantas e frutos. Muitos deles desempenham, na realidade, funções de protecção na planta: anti-oxidantes, biocidas, etc. Muitas das cores visíveis na natureza pertencem a uma das famílias deste grande grupo que são os polifenóis: os flavonóides, nos quais, por sua vez, se integram as antocianinas (azuis e vermelhos) e as flavonas (amarelos).

\section{Antocianinas: azuis e vermelhos das plantas}

Como referido, muitos dos azuis e vermelhos existentes nas plantas derivam das antocianinas (ver estrutura geral do cromóforo na Figura 7) [11]. Estas absorvem fortemente na região do verde

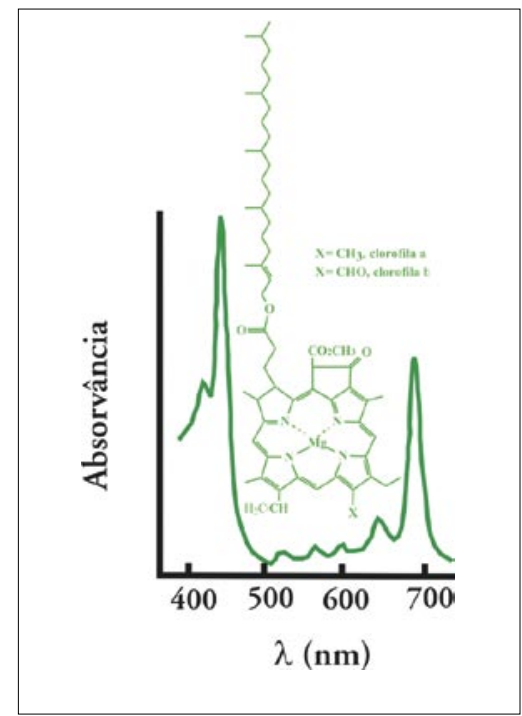

Figura 5 Espectro de absorção da clorofila (estruturas das clorofilas a e b inseridas) na região do visível. Note-se que a absorção na região compreendida entre os 490 e $530 \mathrm{~nm}$ (verde) é muito baixa.

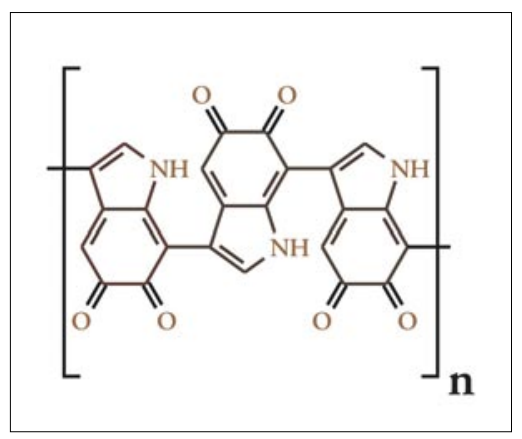

Figura 6 Estrutura do polímero de eumelanina.

\footnotetext{
1 O termo conjugação em sistemas envolvendo electrões $\pi$ pode ser visualizado como electrões que se encontram deslocalizados ao longo das orbitais atómicas 2p não se encontrando confinados a um dado átomo ou mesmo ligação. Em sistemas poliénicos conjugados (sistemas com ligações carbono-carbono simples e duplas alternadas) o seu máximo de absorção encontra-se deslocado para maiores comprimentos de onda consoante o número (crescente) de ligações duplas do sistema. Isto resulta dos níveis energéticos, envolvidos na transição electrónica, diminuirem com o aumento de duplas ligações. A forma como esta diferença energética se relaciona com os espectros electrónicos de polienos pode ser interpretada quantitativamente através do conhecido modelo da partícula (electrão) numa caixa de potencial $[9,10]$.
} 


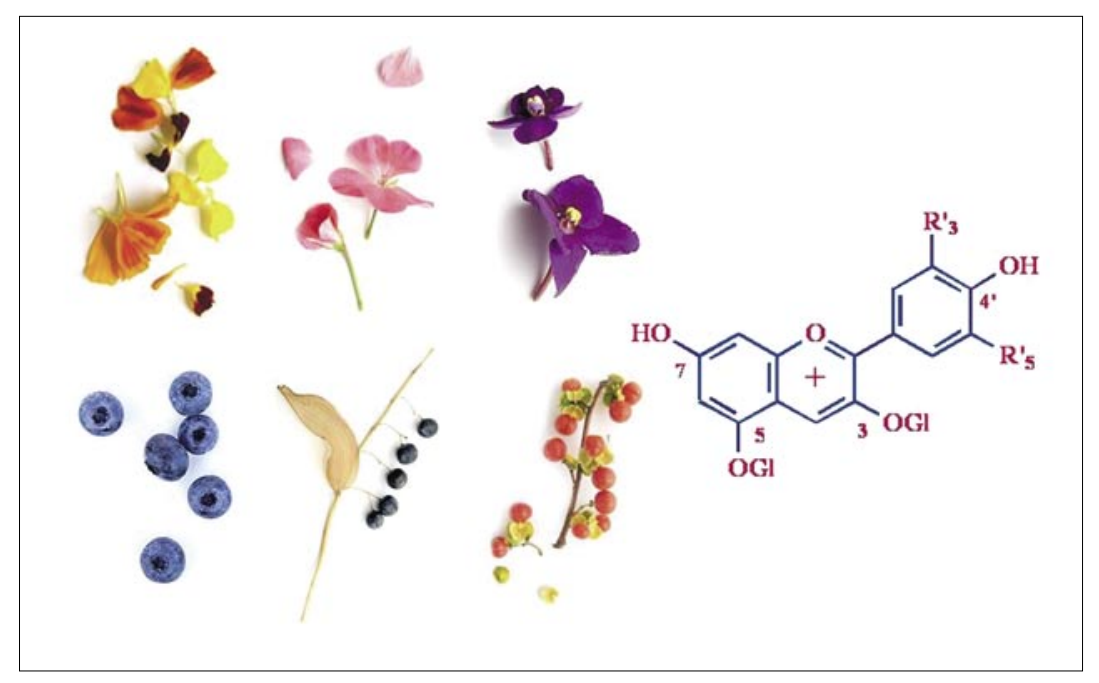

Figura 7 Alguns exemplos de azuis e vermelhos em plantas resultantes das antocianinas. $\AA$ direita, estrutura genérica de uma antocianina, onde nas posições 4' e 7 se encontram grupos hidróxido e nas posições 3 e 5 se representam os grupos glicosídicos; normalmente existe um açúcar na posição 3, podendo ou não coexistir com um outro na posição 5.

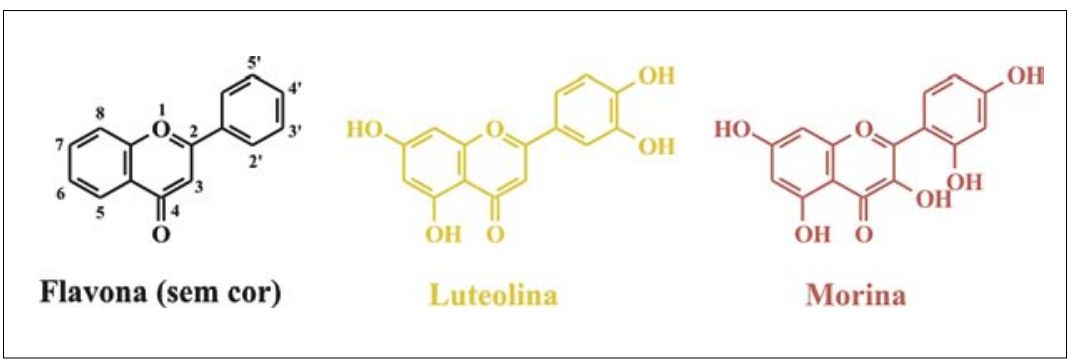

Figura 8 Estruturas da flavona e de outros dois flavonóides, a luteolina e a morina.

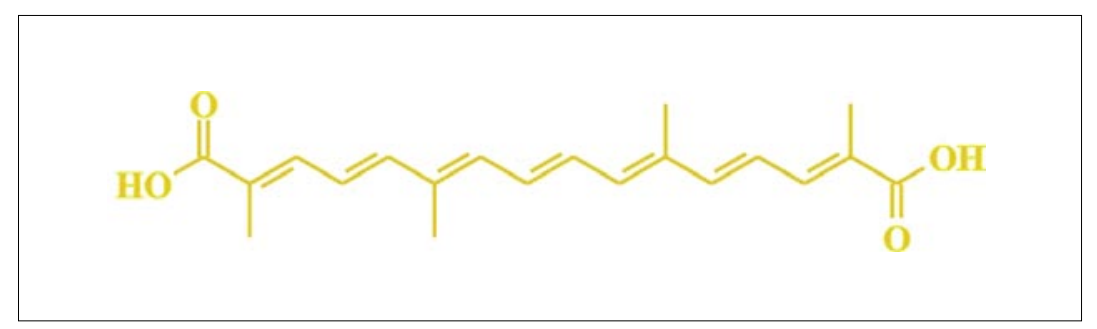

Figura 9 Estrutura da crocetina, um dos polienos responsáveis pela cor amarela dos estigmas do açafrão

( $\lambda_{\max } \approx 510 \mathrm{~nm}$, com envelope espectral na zona dos 450-550 nm) ou do laranja ( $\lambda_{\max } \approx 590 \mathrm{~nm}$, com envelope espectral na zona dos 550-650 nm) do espectro do visível. As flores reflectem então os vermelhos e azuis, que se combinam para dar origem a variadas cores de púrpura a vermelho. Apesar de partirmos de uma estrutura química aparentemente simples, os sistemas criados em solução são complexos, uma vez que se estabelecem uma série de equilíbrios, envolvendo reacções ácido-base, da Commelina communis ou da Centaurea cyanus [12], que é criada por um processo de auto-agregação ("self-assembly").

\section{As Cores na Arte}

A grande maioria das moléculas de origem natural, anteriormente descritas, podem ser consideradas como corantes (moléculas solúveis no meio), mas sendo facilmente fotodegradados, ou seja, pouco estáveis à luz, não foram utilizadas de forma relevante pelo homem como materiais pictóricos ou para tingir têxteis.

$\mathrm{Na}$ actualidade, para fins de tingimento, os corantes utilizados possuem, quase todos, origem sintética. Isto deve-se a diversos factores. Nomeadamente, ao facto de ser mais viável economicamente obter em larga escala produtos por via sintética. Para além de originarem cor, os corantes necessitam de ter associadas outras propriedades. Por exemplo, o corante deve poder fixar-se num determinado tecido e ser estável. Actualmente existem mais de 7000 corantes sintéticos comercialmente acessíveis para as mais diversas aplicações [1]. No entanto, há uns séculos atrás tal número era muito reduzido, sendo todos eles extraídos da Natureza. Iremos aqui passear um pouco por entre estes corantes históricos e, em particular, iremos visitar aqueles que se considera serem as fontes das cores primárias: azul, vermelho e amarelo. Por fim falaremos, brevemente, daquele que foi um dos mais importantes marcos da indústria química: o primeiro corante sintético - a malva.

\section{Amarelos}

Flavonas

cis-trans [11]. Nas antocianinas, apenas duas das espécies produzidas possibilitam a criação de vermelhos e azuis que são, respectivamente, o catião flavílio e a base quinonoidal. Não sendo as espécies termodinamicamente mais estáveis existentes neste sistema, de complexos equilíbrios, foi necessário desenvolver estratégias para as "capturar", o que a Natureza conseguiu de forma maraviIhosa, como é o exemplo da estrutura supramolecular responsável pelo azul
Encontramos alguns dos amarelos mais importantes, para o tingimento de têxteis no passado, nas flavonas e nas 3-hidroxi flavonas (Figura 8) [13]. Estas pertencem, tal como as antocianinas, à grande família dos flavonóides. Na Europa, para obtenção destes amarelos, foram muito utilizadas quer plantas como o lírio-dos-tintureiros (Reseda luteola), quer as bagas do espinheiro-cerval, (Rhamnus cathartica), ou do espinheiro dos tintu- 
reiros (Rhamnus saxatlis) [13]. Este tipo de bagas, Rhamnus spp, era comercializado com os nomes de bagas de Avinhão ("graines d'Avignon") ou da Pérsia (Persian berries) [14]. A luteolina e a morina são exemplos de dois importantes cromóforos para os amarelos extraídos deste tipo de plantas, ver figura 8. Pode observar-se que a introdução de grupos

dos carboxílicos livres (desenhados no cromóforo da Figura 9) encontram-se na forma de éster, sendo o grupo substituinte um açúcar. Estes podem existir na forma de mono ou di-ésteres e os açúcares também podem variar, dependendo da região e variedade da planta.

\section{Vermelhos}

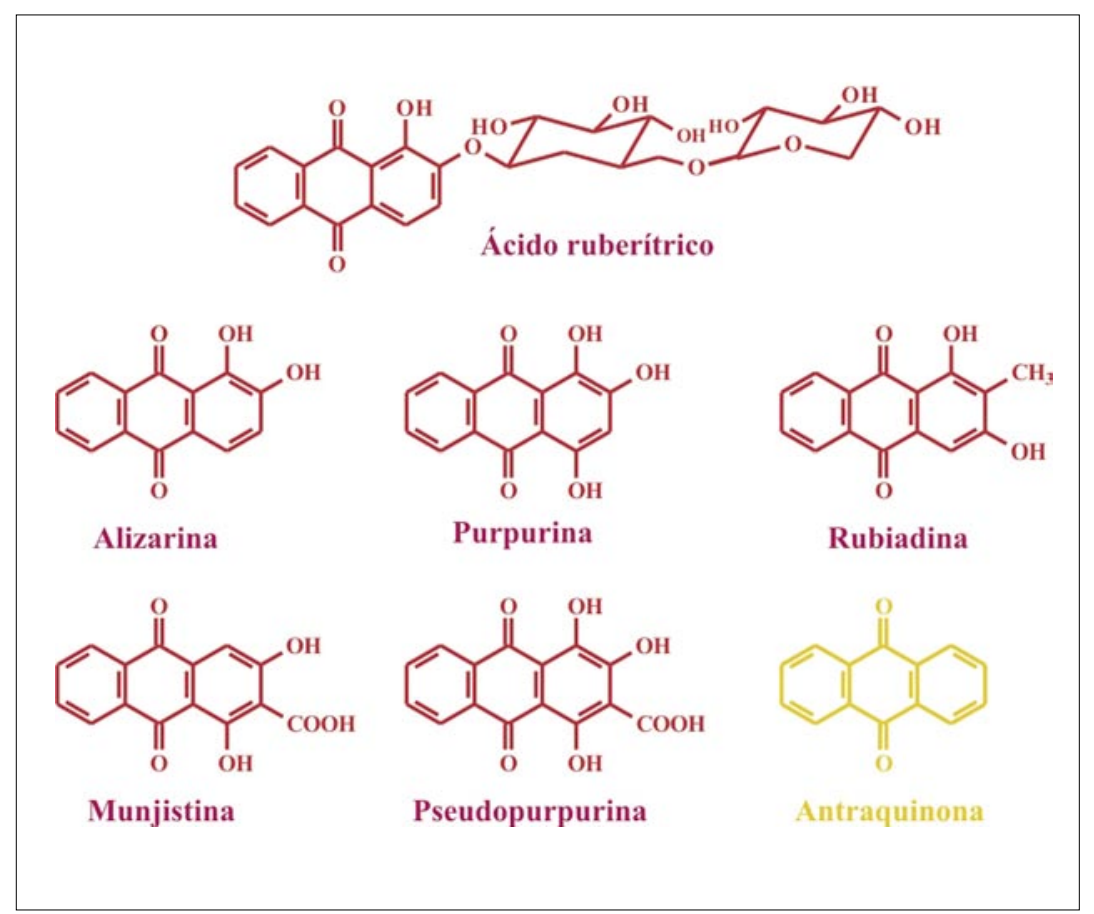

Figura 10 Estruturas dos principais pigmentos extraídos das raízes da garança.

hidroxilo, $-\mathrm{OH}$, faz com que os compostos passem de incolores (nenhum grupo $\mathrm{OH}$, flavona) para laranja (5 grupos $\mathrm{OH}$, Morina).

\section{Carotenóides}

As fontes de amarelo da antiguidade são vastas. Como já se disse os flavonóides são utilizados em muitos dos amarelos que encontramos na natureza. No entanto, o açafrão, Crocus sativus - sim, esse que serve de tempero a muitos dos nossos pratos! - foi também uma importante fonte de amarelo da antiguidade; muito apreciado para tingir um dos tecidos mais amados e cobiçados na Europa da Renascença: a seda. A seda bem tingida com açafrão adquire tonalidades douradas de magnífico efeito [15]. O cromóforo responsável pelo amarelo é a crocetina, figura 9, que se encontra nos estigmas da planta do açafrão na sua forma glicosilada; ou seja os áci-
Os vermelhos de antraquinona

Uma das fontes mais utilizadas na antiguidade para obtenção de vermelho foi a alizarina. Esta foi obtida, durante séculos, por extracção das raízes de plantas, como p.e., a Rubia Tinctoria, vulgo garança (Madder em inglês, Robbia para os italianos e Garance em França). O corante era fixo com o auxílio de um mordente. De facto a civilização Egípcia já possuía a técnica de tingir com mordente ${ }^{i}$, como por exemplo com o alúmen [16-18].

A sua obtenção, a partir de derivados do petróleo, cujos resíduos na altura não tinham qualquer aproveitamento, chega em 1868, através de Graebe e Liebermann, que anteriormente a tinham isolado e caracterizado quimicamente. A síntese da alizarina constitui um duplo marco histórico: provou-se que se podia sintetizar um corante - uma molécula de grande valor comercial - antes só encontrada na Natureza e através do conhecimento prévio da sua estrutura molecular; ou seja, a sua obtenção não foi fruto de um acaso, mas sim do conhecimento da sua estutura química. Curiosamente, em 1869 Perkin (o "inventor" da malva, ver mais à frente) sintetizou a alizarina. No entanto, a empresa BASF ("Badische Anilin- und Sodafabrik", Fábrica da soda e anilinas) ultrapassou-o por um dia (!) no processo de colocar a patente da síntese; mais tarde, chegaram a um acordo, para que Perkin tivesse os direitos de produção para a Grã-Bretanha e a BASF para o resto do mundo [19].

O ácido ruberítrico (Figura 10) constitui a forma como a alizarina se encontra nas raízes frescas de garança, devendo-se o seu isolamento (efectuado entre 1846 e 1856) a Henry Schunck [20,21]. No processo de extracção são retiradas das raízes secas, juntamente com a alizarina, outras moléculas corantes (antraquinonas com diversas substituições) que originam a cor vermelha do seu extracto. Na figura 10 apresentam-se as estruturas de alguns destes principais corantes. Note-se que todos eles possuem um "núcleo" comum de antraquinona. Daqui cumpre destacar a purpurina. Esta molécula, tal como a alizarina, apresenta uma cor vermelha, mas muito mais luminosa. É uma molécula que para além de absorver luz, a emite de uma forma mais intensa.

Pode-se observar que a estrutura da alizarina (Figura 10) possui dois grupos -OH. É pois de suspeitar que a sua cor seja dependente do $\mathrm{pH}$, o que se verifica. A alizarina possui multi-equilíbrios ácido-base tanto no estado fundamental como no estado excitado, com três diferentes bandas de absorção e de emissão que dependem do $\mathrm{pH}[22]$, o que condiciona, obviamente, a sua cor. Afinal não são só as antocianinas a possuírem a capacidade de mudar a cor das plantas! $\mathrm{O}$ resultado desta dependência com 0 $\mathrm{pH}$ é que a alizarina possui dois $\mathrm{pK}$ a de estado fundamental $(7,0$ e 11,5$)$ e dois de estado excitado $(-0,16$ e 5,1), função dos seus dois grupos $-\mathrm{OH}[22,23]$. 

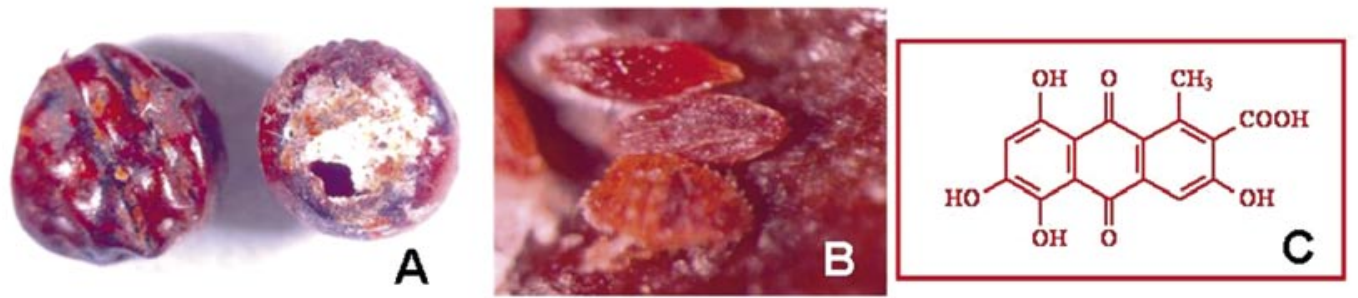

Figura 11 Fitoparasitas do tipo Coccus ilicis : A) fêmea excicada (ampliação de 12,5 x) e B) pormenor dos ovos que se podem ver dentro e sobre a carapaça do insecto (ampliação de $63 \mathrm{x}$ ), C) estrutrura química de uma das moléculas mais representativas da cor vermelha no quermes: o ácido quermésico. (os insectos foram amavelmente oferecidos por $E$. Wallert e foram adquiridos na Turquia).

Muito importantes como materiais pictóricos em pintura são as lacas ${ }^{\mathrm{ii}}$ de alizarina, complexos neutros de alizarina e ião alumínio, muitíssimo utilizadas em iluminura e também em pintura. Ainda que sejam "vermelhos" mais vulneráveis à luz que a maioria dos pigmentos inorgânicos, a sua cor foi irresistível para os grandes artistas. Tanto Piero della Francesca como Van Gogh [24] as utilizaram profusamente. Estas lacas são obtidas a partir da precipitação do extracto de raízes da garança, constituindo uma mistura de complexos neutros de alumínio com alizarina, purpurina e outras eventuais antraquinonas existentes na raiz. Dito de outra forma: o resultado da precipitação é uma laca de garança. A sua cor é de um tom rosa pálido porque existem também hidroxocomplexos de alumínio que são brancos. Em princípio, os complexos octaédricos mais estáveis formados entre o $\mathrm{Al}^{3+}$ e a antraquinona são na proporção de 1:2 (2 de antraquinona, p.e., alizarina para 1 de $\mathrm{Al}^{3+}$ ) sendo o número de coordenação 6 completado com moléculas de $\mathrm{H}_{2} \mathrm{O}$ ou iões $\mathrm{OH}^{-}$.

Outras fontes de vermelho de antraquinona (animais)
Outra importante fonte de vermelho da antiguidade foi o quermes. $\mathrm{O}$ quermes é, tanto quanto se saiba, um dos vermeIhos mais antigos utilizados pelo homem na Europa. É um parasita (figura 11) que existe na Europa e Mediterrâneo desde há tempos imemoriais. Os antigos sabiam que era um verme, sugerindo-se que a origem da palavra vermelho advém do latim vermiculum[25]. O quermes é extraído dos insectos fêmea Coccus ilicis (ou Kermes vermilio), previamente secos, que se encontram em certas espécies de Quercus. O componente fundamental que Ihe dá cor é o
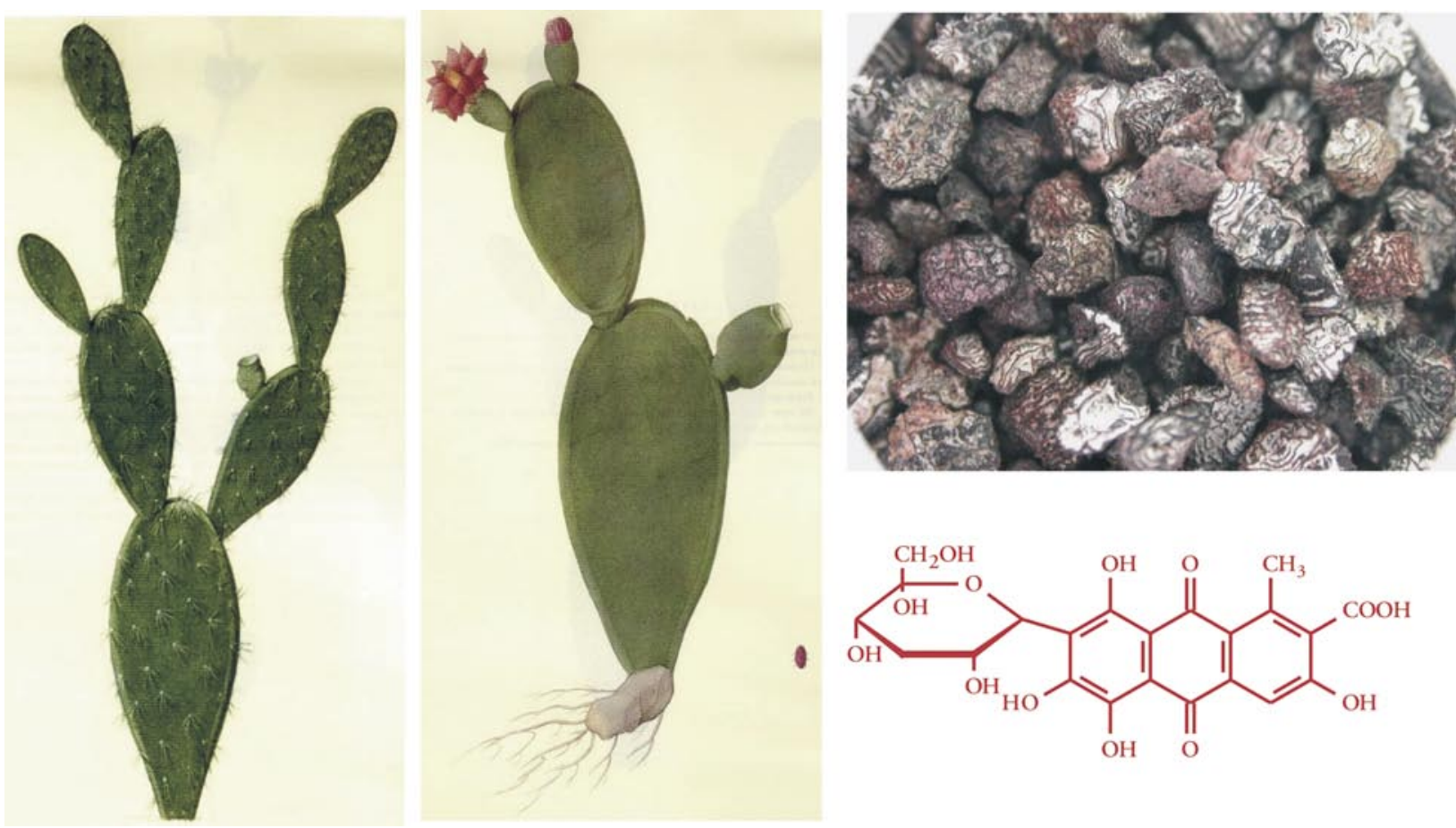<smiles>Cc1c(C(=O)O)c(O)cc2c1C(=O)c1c(O)c(C3OC(O)C(O)C[C@H](O)C3O)c(O)c(O)c1C2=O</smiles>

Figura 12 À esquerda, desenho de uma Palmatória-comprida (família Cactaceae), existente no Brasil. Note-se o pormenor no canto inferior direito que é de uma cochonilha ou cochinilha (fonte de vermelho); à direita cochinilha seca (em cima) e estrutura química do ácido carmínico (em baixo). As figuras da Palmatória comprida foram retiradas da referência [27] com autorização de Fernando Catarino. 
ácido quermésico, também uma antraquinona. O quermes podia ser vendido na forma de pequenas pastilhas de cor vermelho-acastanhado, que possuíam o tamanho de uma ervilha. Esta pastilha, ou pequena bola, consistia na carcaça seca da fêmea do insecto quermes e respectivos ovos, onde se encontrava a matéria colorante[26].

Muito mais tarde, aquando da descoberta dos novos mundos, foi encontrado um outro parasita cuja fonte de vermeIho era muito mais concentrada: a cochinilha ou cochonilha (Dactylopius coccus, antigamente conhecido por Coccus cacti), ver figura 12. A cochinilha foi pela
O ácido carmínico é o principal componente corado da cochinilha, mais uma vez uma antraquinona. A cochinilha seca, ou seja "liofilizada" constituía a forma como era exportada e por isso mesmo difícil de distinguir a sua fonte, ver figura 12. Eis a razão porque o segredo se manteve tanto tempo.

A cochinilha é um parasita de certos tipos de cactos; duas dessas espécies (Palmatória comprida e Palmatória-decochonilha) encontram-se representadas nas magníficas estampas da autoria do Bacharel Jorge Dias Cabral, sendo a reprodução de uma delas apresentada na figura 12. Esta pertence a um con-<smiles>CC(=O)NCCc1ccc(O)c(-c2c(O)c(O)c3c(c2O)C(=O)c2cc(O)c(C(=O)O)c(C(=O)O)c2C3=O)c1</smiles>

Figura 13 Estrutura do ácido lacaico encontrado no Laccifer lacca.

primeira vez comercializada pelos espanhóis no séc. XVI, que a trouxeram dos Novos Mundos que colonizaram [14]. A cochinilha destronou completamente o quermes, tendo tido um grande sucesso como fonte de corante vermelho. Tal ficou essencialmente a dever-se ao facto de possuir muito maior concentração de corante (ácido carmínico) que o parasita nativo europeu ${ }^{2}$. No entanto, os espanhóis guardaram durante muito tempo segredo sobre a natureza da fonte, desconhecendo-se na Europa de então se o corante era vegetal, animal ou mineral! Foi no entanto, um segredo cobiçado e desvendado, como a seguir se verá. junto reunido numa missão de exploração dos sertões do Maranhão e Piauí, que foi levada a cabo, entre outros, pelo já referido Bacharel Jorge Dias Cabral, a pedido do capitão-general da Capitania do Maranhão, D. Diogo de Sousa. O Bacharel foi encarregue de efectuar diligências "relativas ao Reino Vegetal", missão bem sucedida e da qual resultou um documento elaborado em finais do século XVIII e que chegou a Lisboa nos primeiros anos do século XIX [27]. O texto que acompanha as estampas é também da autoria do Bacharel, encontrando-se a Palmatória-comprida descrita com rigoroso detalhe (sublinhado nosso):
"Esta palmatória é mais rara, a pequena altura da antecedente é compensada com a multiplicidade incrível do mesmo pé, e esta pelo contrário se eleva a 7 e 8 pés.

Somente a encontrei na travessia do Coroatá para Caratins, (...), donde concluo que é própria só de serras e catingas.

0 tronco é simples, cresce até 7 e 8 pés, com poucos ramos, as articulações mais comprida que da rasteira, em número de 7,8 e 9 .

Muitos espinhos dispostos em roca por todo o tronco e articulações, setáceos como alfinetes, muito penetrantes e brancos. A baga oval ou mais alongada. A flor também tem a cor vermelha-afogueada. Esta é mais cómoda para a colheita da cochonilha. De ambas vão exemplares vivos."

$\mathrm{Na}$ actualidade a cochinilha, tal como a maioria dos corantes da antiguidade, deixou de servir como fonte de vermelho para o tingimento; constitui, no entanto, um muito utilizado corante alimentar dando, por exemplo, a forte cor vermeIha dos "smarties" ou pintarolas.

Já que nos encontramos no mundo dos insectos produtores de corantes, é de realçar que existia na antiguidade uma terceira importante espécie de insectos fitoparasitas, que crescem na Índia e no sudeste da Ásia, o Laccifer lacca[14]. $\mathrm{O}$ insecto produz uma resina conhecida por goma-laca da qual se extrai o material, corante vermelho, que é, mais uma vez, um derivado da antraquinona (ver figuras 10 e 13). Sabe-se que na Índia este corante era usado desde tempos ancestrais para tingir a seda, e que, pelo menos desde 1220, a resina foi comercializada em Espanha e Provença para tingir. Da resina após maceração em água extraía-se o material corante e da solução aquosa, que era posteriormente evaporada, faziam-se bolos. O corante de tingimento contém, como principal componente de cor, o ácido lacaico (ver Figura 13). A resina, apenas solúvel em etanol ou outros solventes orgânicos,

\footnotetext{
20 insecto ao ser seco perde cerca de $1 / 3$ do seu peso. Para além disso e ao contrário do quermes onde só (no máximo) duas colheitas de ovos do insecto são possíveis de efectuar por ano, no caso da cochinilha são possíveis três [26].
} 
era também comercializada, como verniz goma-laca.

Os vermelhos de pau iii

A brazileína, um dos compostos extraídos do Pau do Brasil, tem um significado especial para os povos de Portugal e do Brasil, dado que o nome Brasil advém da cor das árvores de onde este composto era extraído, sendo que o nome originalmente pensado pela coroa Portuguesa era o de Terra da Vera Cruz[28]. Conta a História, que a cor apresentada pelas árvores que Pedro Álvares Cabral e seus navegadores primeiramente avistaram ao chegar à Terra da Vera Cruz, no ano de 1500, era idêntica às das brasas de uma fogueira. De facto, quando os navegadores portugueses chegaram à costa brasileira encontraram uma vasta floresta rica em árvores utilizadas pelos índios como fonte de corantes vermelhos. Notaram então, que as árvores eram semelhantes às que traziam da Ásia e que designavam por "Pau do Brasil". A madeira do Pau do Brasil era considerada uma madeira de alta qualidade, pois era densa, dura e compacta, muito resistente e de textura fina.

Presentemente, designam-se por Pau do Brasil ou Pau de Pernambuco os corantes vermelhos de origem natural que se obtêm da madeira da Caesalpinia brasiliensis.

Antes de conhecido o Pau de Pernambuco e durante a Idade Média estas madeiras eram importadas da Ásia, p.e. do Sri Lanka (antigo Ceilão). Contudo, as árvores existentes na Ásia e na América do Sul são espécies diferentes. A versão sul-americana é a Caesalpinia echinata (Lamarck), enquanto a asiática é a Caesalpinia sappan L.. A confusão aumentou ainda mais com a descoberta, na América Central, de uma outra fonte de madeira vermelha pertencente à espécie Haematoxylum brasiletto (Karsten) [14] .

De facto, devido ao desbaste ao qual a floresta brasileira foi submetida, durante o período de 1501 a 1652, para obtenção do Pau do Brasil (ou de Pernambuco), com subsequente comercialização na Europa, a árvore original foi gradualmente substituída pela Haema-

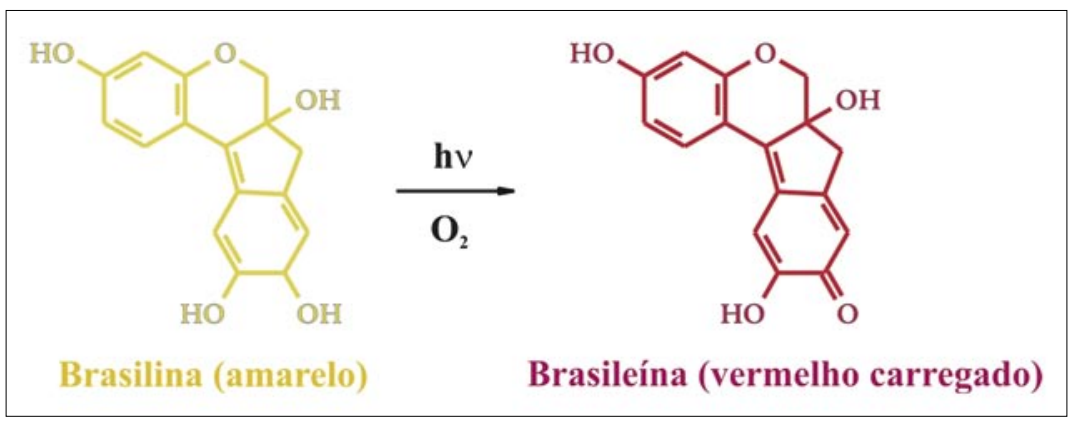

Figura 14 Estruturas químicas dos principais constituintes que dão a cor ao Pau do Brasil, explicitando-se a reacção de foto-oxidação com conversão de um dos grupos hidróxilo da brasilina em grupo carbonilo na brasileína.

toxylum brasiletto da América Central, que ficou igualmente conhecida como Pau do Brasil, contribuindo para aumentar a confusão entre os botânicos e historiadores.

Quimicamente, o principal componente que dá a cor e é isolado da Caesalpinia é a brasilina que quando exposto ao ar (sujeito ao oxigénio, $\mathrm{O}_{2}$ na figura 14 ) e à luz ( $v$ na figura 14 ) oxida-se dando origem à brasileína (ver figura 14).

Outras fontes de vermelho da antiguidade são, por exemplo, a resina de dragoeiro, Dracaena draco. Em Portugal, nomeadamente na Madeira onde a espécie é nativa, existem alguns belíssimos e centenários exemplares.

\section{Azuis}

\section{O mítico índigo}

Os derivados do índigo, nos quais se inclui a púrpura (Figura 15) constituem provavelmente os corantes azuis mais antigos utilizados pelo homem [11]. As fontes de origem natural para obtenção do índigo são muito diversificadas, conhecendo-se, da Indigofera, mais de 700 espécies espalhadas por todos os continentes: tinctoria, suffruticosa, arrecta, argentea, etc. No entanto, na Europa (Centro e Sul) o índigo era obtido a partir da Isatis tinctoria, da qual se obtém um produto com muito menos concentração de azul quando comparado com algumas espécies Indigofera. Em Portugal é conhecida por pastel ou pastel-dos-tintureiros (em inglês "woad", em francês "pastel", em italiano "guado"); dada a sua importância económica, pensa-se que deu azo à expressão "tens pastel?", como quem diz "tens dinheiro?" [29].

A importância comercial da Indigofera tinctoria era tão grande que nos tempos da Rainha Isabel de Inglaterra, o índigo era importado para a Europa e Inglaterra, mas devido a protestos dos produtores de pastel a sua importação teve de ser banida [30].

\section{A púrpura}

A púrpura (Figura 15) foi talvez a cor mais importante na representação do poder, dado que só o imperador Romano podia aparecer em público com um manto tingido de púrpura, enquanto

Figura 15 Estruturas do Índigo e da Púrpura.

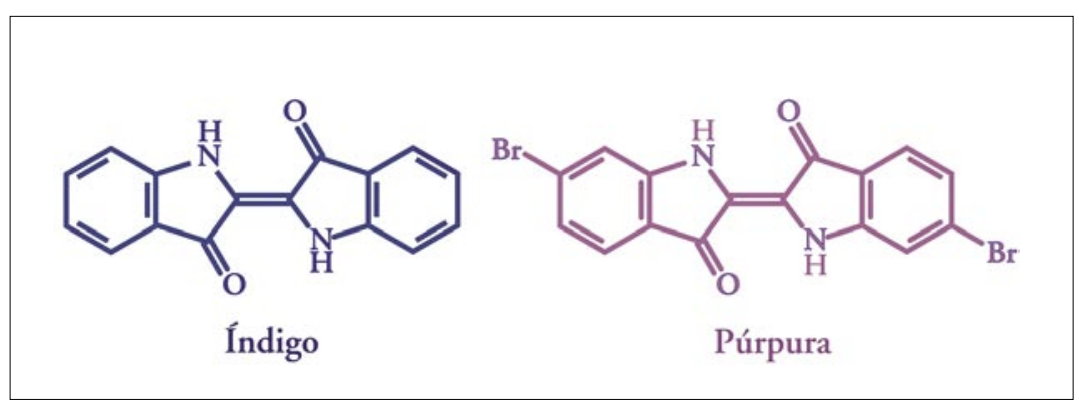


que a outros altos dignitários estaria reservado apenas o uso de uma barra de púrpura.

A púrpura constitui um exemplo de um derivado bromado do índigo (figura 15), sendo obtida a partir das glândulas de moluscos do género Purpura, mas também de moluscos Murex trunculus dos quais ainda existem vestígios de grandes quantidades esmagadas (formando autênticos montes). Estima-se que eram necessários cerca de 9000 moluscos para produzir 1 grama de corante [31]. A sua extracção exaustiva conduziu ao primeiro desastre ecológico de que há memória na história da humanidade [32,33].

Em Portugal uma das espécies é conhecida por canilha e genericamente por búzios, encontrando-se nos mercados junto com outros moluscos.

O azul dos Hebreus: o "tekhelet"

Aquando do êxodo dos judeus do Egipto, o tekhelet (azul) e o argaman (púrpura) eram artigos bem conhecidos do mundo antigo [34]. São mencionados no Antigo Testamento juntamente com o ouro e a prata na lista de materiais necessários para o Tabernáculo (santuário em forma de tenda amovível utilizado pelos Hebreus).

No Antigo Testamento Deus ensina os Israelitas a usarem, no xaile utilizado para a oração, algumas franjas de cor tekhelet. Estas franjas deveriam ter sido coradas com o "azul bíblico" ou tekhelet. O segredo da obtenção do tekhelet original perdeu-se nas dobras do tempo, e a procura da verdadeira origem do corante ainda hoje não se encontra totalmente esclarecida, não existindo sequer consenso sobre qual seria a cor original designada por tekhelet[35]. Pensa-se que o corante seria obtido, de forma idêntica à da púrpura, a partir de três espécies de moluscos que se encontram no Mediterrâneo. A cor exacta do corante obtido ia do azul claro à púrpura escura, dependendo igualmente da estação e do sexo do molusco. Note-se que por motivos religiosos a cor sagrada deve ser obtida a partir do búzio.
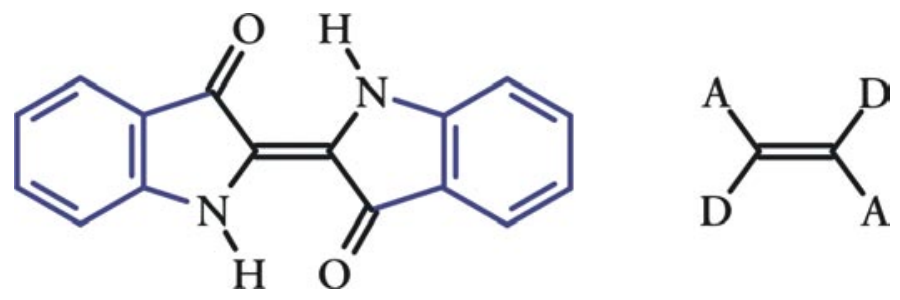

Esquema 1 A molécula de índigo com os seus grupos aceitador e doador de electrões. A= grupo aceitador de electrões e $\mathrm{D}=$ grupo doador de electrões

\section{A via sintética}

Um outro exemplo histórico ajuda a perceber a importância do índigo no século XIX. Durante as invasões napoleónicas, o exército de Napoleão (cujos trajes eram tingidos com pastel para o azul e garança para o vermelho) viu-se privado do seu mercado principal: as colónias asiáticas. A planta europeia (nela se inclui a francesa) era muito mais pobre em índigo que as asiáticas. Ciente da importância do índigo, Napoleão ofereceu uma recompensa de 1 milhão de Francos franceses a quem conseguisse fabricar índigo sintético! A história conta que este prémio nunca foi reclamado.

Em 1865 Adolf von Bayer ${ }^{3}$ iniciou o seu trabalho de síntese do índigo. Alguns anos mais tarde descobriu a sua estrutura química e estabeleceu um possível caminho sintético para o índigo. A necessidade de obtenção desta molécula resultava da sua extrema importância económica à época, o que fez com que a firma BASF investisse milhões na investigação de um caminho sintético com viabilidade económica [36]. O índigo sintético teve então o condão de puxar pelo desenvolvimento da gigantesca indústria química alemã, mas também de fechar o ciclo colonialista da produção de índigo que até ali tinha vindo de fontes naturais existentes na Inglaterra, colónias Inglesas, França e colónias Ibéricas [30]. Tal afectou em particular a colónia inglesa da Índia, o principal produtor da época. Ainda agora, no início do século XXI, o índigo constitui, surpreendentemente, um moderno e importante corante sabendo-se que a investigação da sua produção, tendo como base conceitos de química verde, a partir de micro-organismos, se encontra em pleno desenvolvimento [37,38].

\section{As duas formas do corante índigo}

Os derivados do índigo são normalmente conhecidos como corantes de tina (em inglês vat dyes), sendo insolúveis em água [39]. Uma característica destes corantes consiste na existência, na sua estrutura química, de um ou mais grupos carbonilo que, quando tratados com um agente redutor e na presença de uma base, formam um corante solúvel em água conhecido como a forma ou base leuco. O processo de tingimento, de tina, de um têxtil envolve precisamente a redução do corante a uma forma que é solúvel, normalmente desprovida de cor, com aplicação no tecido (por mergulho deste na solução do corante em meio básico e redutor) seguida de oxidação pelo ar por forma a obter-se novamente a forma corada, oxidada e insolúvel [40]. Curiosamente, na antiguidade, a urina era frequentemente utilizada como o agente redutor; leia-se por exemplo o texto "Tapetes de arraiolos" de D. José Pessanha incluída na Separata d' "O Archeologo Português", XI, n. ${ }^{\text {os }} 5$ a 8 de 1906, onde é descrito como o tingimento com anil dos tapetes de Arraiolos necessitava para que a lã adquirisse o tom azul cerca de três dias em solução de urina num tacho! [40].

\footnotetext{
3 Em 1905 os seus trabalhos na área da química orgânica foram reconhecidos com o Prémio Nobel da Química: "in recognition of his services in the advancement of organic chemistry and the chemical industry, through his work on organic dyes and hydroaromatic compounds".
} 
O índigo é igualmente um dos mais estáveis corantes têxteis orgânicos. Este facto explica, em parte, não só o seu uso diversificado na antiguidade e na idade pré-moderna, como também a sua longevidade como corante. A estabilidade do índigo é também a razão porque ele foi utilizado por alguns dos grandes mestres da pintura dos séculos XVII e XVIII na pintura a óleo, como Rubens [41,42]. Curiosamente o índigo mais conhecido, azul índigo, ainda hoje é utilizado para tingir os famosos "bluejeans"[43].

\section{A Fotoquímica-Fotofísica do Índigo}

Para os químicos, a explicação da cor azul do índigo, e em geral da cor dos seus derivados, tem-se revelado um tema intrigante mas igualmente fascinante, tendo sido explorado com detalhe e engenho durante as décadas de 1970 e 1980 [44-47]. Descobriu-se então que o cromóforo responsável pela cor inclui a ligação dupla central (entre os dois anéis de indole) juntamente com os átomos de azoto e os grupos carbonilo (Esquema 1) [46]. De facto, o índigo deve a sua forte batocromicidade (desvio da cor para comprimentos de onda mais elevados) ao arranjo espacial conferido pelos grupos doador (-NH-) e aceitador $(-\mathrm{C}=\mathrm{O})$, formando o que foi designado como um cromóforo-H, devido à sua geometria (ver esquema 1) [45].

No processo de tingimento de um tecido e como atrás se mencionou, o índigo possui duas formas: aquela que o torna solúvel em água (forma reduzida ou leuco) e a forma na qual resplandece o seu azul (a forma ceto). Ambas adquirem, por isso, propriedades espectrais e

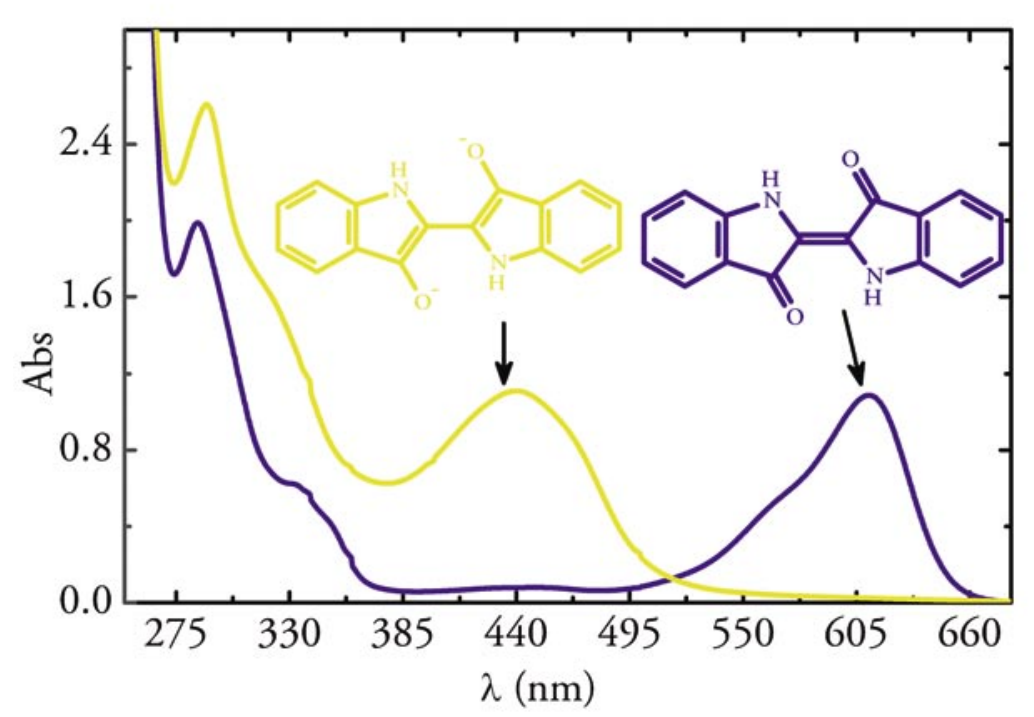

Figura 16 Espectros de absorção do índigo em solução de dimetilformamida nas suas formas leuco e ceto. No caso da forma leuco, esta é obtida pela adição de umas gotas de uma solução aquosa de ditionito de sódio e hidróxido de sódio [40].

fotoquímicas bem diferenciadas, absorvendo em regiões bem distintas do espectro do visível (Figura 16) e emitindo fluorescência também em regiões e com intensidades muito diferentes [48] Note-se que a ligação central entre os dois anéis passou de uma ligação dupla (ceto) para uma ligação simples (leuco), ver figura 16. Isto tem como resultado que o grupo responsável pela conjugação (ligação dupla central mais os átomos de azoto e os grupos carbonilo) a perdeu e a molécula de índigo na sua forma leuco absorve para menores comprimentos de onda. Outros parâmetros, como por exemplo o parâmetro que quantifica a capacidade de uma molécula, no seu estado excitado, emitir mais ou menos fluorescência, ou seja o seu rendimento quântico de fluorescência, é cerca de 150 vezes superior no caso da forma leuco do índigo relativamente à sua forma ceto[48]. A molécula excitada, criada após a absorção de luz, pode perder o excesso de energia, i.e, desactivar, por diversas formas: físicas, como p.e. a emissão de fluorescência, ou químicas, p.e., degradando-se. Assim, no caso da forma ceto do índigo é sabido que a sua principal forma de "regresso" ao estado fundamental é através do processo de conversão interna. Suspeita-se que este processo é altamente eficiente devido à possibilidade de rápida transferência de protão entre o átomo de azoto e o grupo carbonilo [48] $\mathrm{Na}$ forma ceto, os outros dois processos de desactivação do estado excitado (fluorescência e formação

Figura 17 A malva planta (flor e folha) e o produto obtido pela síntese de Perkin.
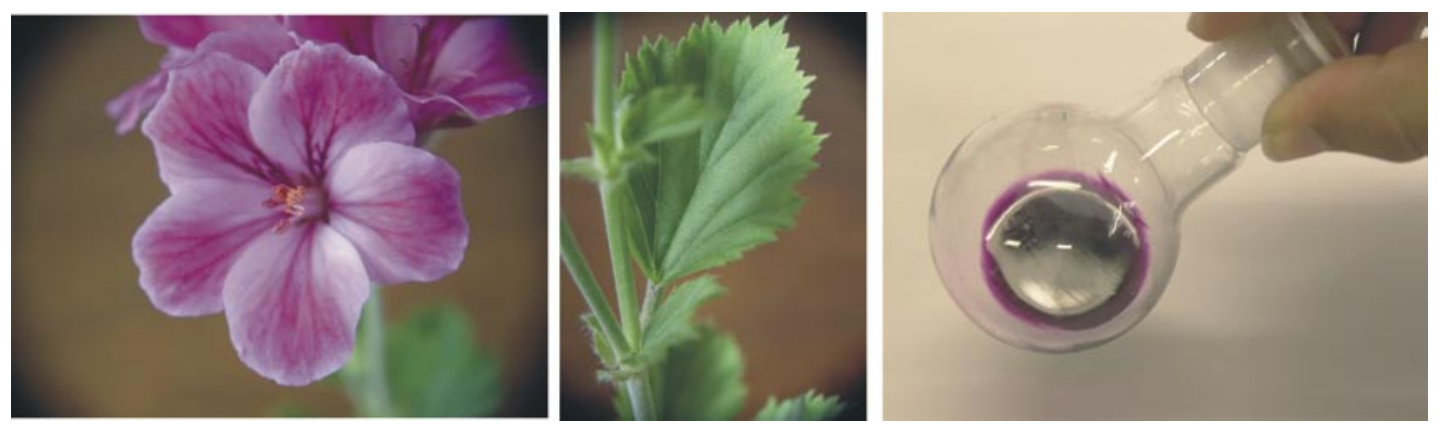
de estado tripleto) são muito pouco eficientes.

No entanto, quando olhamos para a forma leuco do índigo, o panorama muda completamente. Neste caso, o tempo de vida da molécula no estado excitado aumenta significativamente e processos como a emissão de fluorescência ou a criação de outros estados excitados (estado tripleto) apresentam valores de rendimentos muito elevados [48]. Daqui resulta que a molécula de índigo, na sua forma reduzida e excitada, adquiriu uma nova entidade própria. Este fenómeno é igualmente observado com as formas reduzidas (leuco) da púrpura, da indigocarmina e da indirubina [48].

O conhecimento detalhado da fotoquímica/fotofísica do índigo e seus derivados, oferece assim excelentes perspectivas para a compreensão de muitos fenómenos que ocorrem nesta molécula, como por exemplo a explicação para a sua elevada fotoestabilidade [49].

\section{A Malva de Perkin}

A malva (1856) foi o primeiro corante sintético a ser produzido e comercializado. A sua produção marca o início da indústria química de produção de corantes. Durante a Páscoa de 1856, com a idade de 18 anos, William Perkin, o químico que a descobriu, ou melhor dizendo que a criou, deu conta que num dos seus insucessos na tentativa de síntese de quinino iv obtinha um precipitado castanho escuro (quem não se recorda de já ter tido um destes "produtos" resultantes do insucesso de uma qualquer síntese orgânica!) que ao ser lavado deixava na água uma cor púrpura magnífica. Em 1856 não havia qualquer ideia sobre a estrutura das moléculas, ou seja de como os átomos se encontravam ligados entre si. O talento, a argúcia e persistência do jovem Perkin fizeram História. De facto a "malva de Perkin" tem por detrás uma história fascinante[19]. Ao contrário da alizarina, a malva foi sintetizada sem se saber quase nada sobre a sua estrutura molecular, nomeadamente a sua aromaticidade. A sua estrutura só ficou bem determinada em 1994 num artigo publicado numa revista cujo título é Perkin Transactions. A "malva" foi o primeiro corante sintético, não existente na natureza, criado por um Químico. A sua cor é resplandecente e, ainda que obtida como produto minoritário na síntese de Perkin, as soluções resultantes são fortemente coradas (ver figura 17). O roxo é tão forte (escuro) que aparenta um brilho metálico. Após diluição fica com a cor da flor da malva (ver figura 17). Perkin baptizou-a de "Tyrian Purple" dada a sua similaridade com a cor da púrpura imperial, mas foram os franceses a ditarem o nome com que ficou conhecida, muito mais "fashionable", "malva". As sedas tingidas de malva fizeram furor e ditaram a moda na Europa do século XIX. Conta-se que, após ter visto a Imperatriz Eugénie, esposa de Napoleão III, vestida com essa cor, a rainha Vitória de Inglaterra a escolheu para a usar no casamento da sua filha, e, em pouco tempo, nas ruas de Londres a "Malvamania" era total!

\section{Conclusões}

Neste trabalho pretendeu-se dar uma visão diferente da História das cores: aquela que é a visão de um químico que mexe com as moléculas, a luz que com elas interage e a cor que delas sai. O entrar no mundo das moléculas de corantes históricos fez com que olhássemos para as "moléculas da cor" como conteúdo de História. Assim o trabaIho pretende transmitir, em parte, uma visão mista de propriedades químicas das moléculas orgânicas, a sua origem na natureza (animal, vegetal ou mineral) e um pouco da sua cronologia original e histórica. Por razões óbvias tudo isto é efectuado de forma sucinta e cujo detalhe pode e deve ser encontrado noutros lados. Retirámos também e propositadamente deste contexto os pigmentos de origem inorgânica, pois estes têm merecido um tratamento exaustivo neste Boletim pelas mãos do Prof. Peixoto Cabral.

\section{Agradecimentos}

Agradecemos à FCT, FEDER, o financiamento no âmbito dos projectos POCl/ QUI/55672/2004 "As Moléculas da Cor na Arte: um Estudo Fotoquímico", POCTI/ EAT/33782/2000 "A cor na iluminura portuguesa: uma abordagem interdisci- plinar", e a todos os alunos de História e Técnicas de Produção Artística da Licenciatura em Conservação e Restauro da UNL, pelas belíssimas cores produzidas de mãos nuas.

\section{Bibliografia}

[1] J.C.V.P. Moura, Química: Boletim da Sociedade Portuguesa de Química 89 (2003) 75-80.

[2] J.M. Peixoto Cabral, Química: Boletim da Sociedade Portuguesa de Química 66 (1997) 17-24.

[3] J.M. Peixoto Cabral, Química: Boletim da Sociedade Portuguesa de Química 82 (2001) 57-64.

[4] J.M. Peixoto Cabral, Química: Boletim da Sociedade Portuguesa de Química 97 (2005) 39-51.

[5] P. Ball, Bright Earth: Art and the Invention of Color, Farrar, Straus and Giroux, New York, 2002.

[6] K. Nassau, The Physics and Chemistry of Color. The Fifteen Causes of Color, Wiley Interscience, New York, 2001.

[7] A. Bartecki, J. Burgess, The colour of metal compounds, Gordon and Breach Science Publishers, 2000.

[8] R. Tilley, Colour and the optical properties of materials, John Wiley \& Sons, Chichester, 2000

[9] O.C. Monteiro, T. Andrade, Química: Boletim da Sociedade Portuguesa de Química 84 (2002) 49-54.

[10] A.L. Magalhães, J.A.N.F. Gomes, Química: Boletim da Sociedade Portuguesa de Química 41 (1990) 23.

[11] M.J. Melo, A. Roque, F. Pina, Química-Boletim da Sociedade Portuguesa de Química 74 (1999) 41-50.

[12] T. Kondo, K. Yoshida, A. Nakagawa, T. Kawai, H. Tamura, T. Goto, Nature 358 (1992) 515-518.

[13] E.S.B. Ferreira, A.S. Hulme, H. McNab, Q. A., Chemical Society Reviews 33 (2004) 329-336.

[14] D. Cardon, Le monde des teintures naturelles, Éditions Belin, Paris, 2003.

[15] M.J. Melo, Química, Boletim da Sociedade Portuguesa de Química 81 (2001) Folha de Actividades na Sala de Aula \#1.

[16] R. Halleux, editor. Les Alchimistes Grecs. Papyrus de Leyde. Papyprus de Stockholm. Recettes: Les Belles Lettres, 2002 (1. . edição 1981). 
[17] E.R. Caley, Journal of Chemical Education 3 (1926) 1149-1166.

[18] E.R. Caley, Journal of Chemical Education 4 (1927) 979-1002.

[19] S. Garfield, , p. Norton, MAUVE. How One Man Invented a Color That Changed the World, W.W. Norton \& Company, 2002.

[20] C. Cooksey. Ancient dyes, natural and synthetic in http://www.chriscooksey. demon.co.uk/schunck/index.html. Cooksey, C., acedida em Abril de 2005.

[21] C.J. Cooksey, A.T. Dronsfield, Dyes in History and Archaeology, (submetido).

[22] A.P. Moura. Tese de Licenciatura, Departamento de Química da Universidade de Coimbra. Coimbra: Universidade de Coimbra, 2003.

[23] C. Miliani, A. Romani, G. Favaro, Spectrochimica Acta Part a - Molecular and Biomolecular Spectroscopy 54 (1998) 581-588.

[24] A. Burnstock, I. Lanfear, K.J. van den Berg, L. Carlyle, M. Clarke, E. Hendriks, J. Kirby, ICOM Committee for Conservation I (2005) 459-466.

[25] E.W. FitzHugh, editor. Artists' Pigments, a Handbook of theory, history and characteristics: National Gallery of Art.

[26] M. Bender, Journal of Chemical Education 24 (1947) 2-10.

[27] J.E. Mendes Ferrão, F.M. Catarino, M.C. Liberato, M.L. Abrantes, Plantas do Brasil. Flora Económica do Brasil no século XVIII. Plantas do Maranhão-Piauí, IICT - Instituto de Investigação Científica e Tropical, Museu e Jardim Botânico/ Museu Nacional de História Natural da Universidade de Lisboa e Chaves Ferreira - Publicações, S.A., Lisboa, 2002.

[28] La découverte du Brésil. Les premiers témoignages choisis \& présentés par Ilda Mendes dos Santos (1500-1530), Chandeigne, 2000.

[29] comunicação pessoal do Prof. Fernando Mangas Catarino (director do Jardim Botânico de Lisboa) 2005.

[30] J. Cannon, M. Cannon, Dye Plants and dyeing, The Herbert Press Ltd, London, 1994

[31] N.S. Gettys, J. Chem. Ed. 76 (1999) 737-746.

[32] R.J.H. Clark, C.J. Cooksey, M.A.M. Daniels, R. Withnall, Endeavour 17 (1993) 191-199.

[33] C.J. Cooksey, Molecules 6 (2001) 736769.
[34] B. Sterman, Tekhlet, Yeshiva University Press, 1996.

[35] R. Hoffmann, S.L. Schmidt, Old wine, New Flasks. Reflections on Science and the Jewish Tradition, W. H. Freeman \& Company, New York, 1997.

[36] J. Balfour-Paul, Indigo, British Museum Press, 2000.

[37] A. Berry, T.C. Dodge, M. Pepsin, W. Weyler, J. Ind. Microbiol. Biot. 28 (2002) 127-133.

[38] A.N. Padden, V.M. Dillon, P. John, J. Edmonds, M.D. Collins, N. Alvarez, Nature 396 (1998) 225-225.

[39] M. Séquin-Frey, Journal of Chemical Education 58 (1981) 301-305.

[40] J. Seixas de Melo, M. Barroso, Química: Boletim da Sociedade Portuguesa de Química 81 (2000) 66-69.

[41] M. van Eikema Hommes. 20th Annual Meeting of Dyes in History and Archaeology. Amsterdam, 2001.

[42] P. Novotná, J.J. Boon, J. vand der Horst, V. Pacáková, Color Technology 119 (2003) 121-127.

[43] T.M. Brown, C.J. Cooksey, A.T. Dronsfield, Education in Chemistry 38 (2001) 69-71.

[44] M. Klessinger, Angew. Chem. Int. Ed. Engl. 19 (1980) 908-909.

[45] M. Klessinger, W. Luettke, Tetrahedron 19, Suppl. 2 (1963) 315-335.

[46] E. Wille, W. Luttke, Angewandte Chemie-International Edition 10 (1971) 803804.

[47] G. Pfeifer, W. Otting, H. Bauer, Angewandte Chemistry International Edition English 15 (1976) 52-52.

[48] J. Seixas de Melo, A.P. Moura, M.J. Melo, Journal of Physical Chemistry A 108 (2004) 6975-6981.

[49] J. Seixas de Melo, R. Rondão, H.D. Burrows, M.J. Melo, S. Navaratnam, R. Edge, G. Voss, Journal of Physical Chemistry A (submetido).

Notas

i) A palavra "mordente" deriva de uma expressão utilizada para caracterizar um tipo de tingimento, "tingimento com/por mordente"; por oposição a um tingimento directo ou de tina (como o que é efectuado com o índigo). Um mordente cumpre a função de intermediário entre a fibra têxtil e o corante, fixando este último de forma permanente. Exemplos de mordentes, utilizados no passado, são os iões metálicos de alumínio, ferro, cobre, estanho, etc.

ii) A palavra "laca" pode designar materiais pictóricos muito diferentes; assim, laca em português tanto pode designar uma resina corada (a goma-laca indiana, com mais ou menos corante, ou o lacado japonês e chinês, efectuado a partir de uma mistura de uma resina vegetal com um pigmento vermelho ou preto), como um complexo de um corante com um catião (a laca de garança, cochoniIha, de eosina, etc).

No Diccionário Etimológico da língua portuguesa de Pedro Machado, a etimologia da palavra é dada como proveniente do árabe lakka, mesmo sentido, pelo italiano lacca, já documentado no séc. XVI, se bem que também seja acenada uma citação de latim medieval do séc. VIII.

Foram consultados tanto o "Novo dicionário compacto da língua portuguesa" de António Morais Silva, como o "Dicionário Houaiss da Língua Portuguesa", na edição da Temas e Debates de 2003, mas julgamos que o "II grande dizionario Garzanti della lingua italiana", edição de 1987, apresenta uma definição mais clara; este, na sua segunda entrada para a palavra "lacca", descreve-lhe quatro utilizações diferentes: 1 - nome de uso corrente da goma-laca, substância de origem resinosa vegetal com a qual se produz vernizes, adesivos (...)| do Japão, resina vegetal muito utilizada no Oriente para objectos artísticos (...); 2 - pigmento obtido misturando corantes naturais ou sintéticos com compostos inorgânicos, utilizado para preparar tintas para escrever, aguarelas ou tintas a óleo; a tinta em si; 3 - utilizado para fixar os cabelos, normalmente em embalagens de "spray"; 4 - verniz de pintar as unhas.

Pensamos que, o conhecimento das estruturas moleculares e do contexto em que são aplicadas permite o entendimento mais simples e claro da palavra "laca", e foi isso que tentamos fazer no nosso texto.

iii) Para os portugueses a palavra "pau" significa "qualquer pedaço de madeira", e para os brasileiros significa "qualquer árvore".

iv) O quinino só foi sintetizado quase um século depois, em 1944, por Doering e Woodward [The Total Synthesis of Quinine, R. B. Woodward, W. E. Doering; J. Am. Chem. Soc. 66 (1944) 849] tendo sido, parcialmente devida a esta síntese que Woodward recebeu o Prémio Nobel da Química em 1965. 